\title{
ALIMENTAȚIA DIVERSIFICATĂ - SCURTĂ TRECERE ÎN REVISTĂ A UNOR PRINCIPII CORECTE PENTRU O SĂNĂTATE PE TERMEN LUNG
}

\author{
Laura Florescu, Oana-Raluca Temneanu, Dana-Elena Mîndru, Nistor Nicolai \\ Universitatea de Medicină şi Farmacie ,, Gr. T. Popa “, Iaşi
}

\begin{abstract}
REZUMAT
Nutriția reprezintă totalitatea proceselor fiziologice de asimilare şi degradare a alimentelor care au loc într-un organism, necesare creşterii şi dezvoltării. Se mențin de actualitate discuțiile asupra tendințelor în alimentație, numeroase societăți ştiințifice şi comitete internaționale dedicându-şi atenția asupra impactului pe care alimentația corectă o are asupra creşterii şi dezvoltării armonioase, începând încă din viața intrauterină. Introducerea progresivă în alimentația sugarului, după vârsta de 4-6 luni, a alimentelor semisolide şi solide, ce înlocuiesc treptat prânzurile de lapte administrate anterior este cunoscută sub denumirea de alimentație diversificată (complementară). Ultimele recomandări ale Comitetului ESPGHAN (European Society for Pediatric Gastroenterology, Hepatology and Nutrition) privind momentul trecerii de la o alimentație exclusiv lactată la una care să conțină şi alte alimente sunt pentru intervalul de vârstă cuprins între săptămânile 17-26.

O importanță primordială o are complianța şi colaborarea familiei cu medicii. Având în vedere posibilitatea actuală de a accesa numeroase informații, uneori fără o bază ştiințifică, am considerat oportună o scurtă trecere în revistă a principalelor aspecte ale unei alimentații diversificate conform recomandărilor de specialitate.

Cuvinte cheie: alimentație diversificată, sugar, principii de diversificare, alimente de
\end{abstract} diversificare

Nutriţia este ştiinţa alimentaţiei şi a relaţiei dintre aceasta şi sănătate, reprezentând totalitatea proceselor fiziologice de asimilare şi degradare a alimentelor care au loc într-un organism, necesare creşterii şi dezvoltării (1). Nevoile pentru creştere variază în funcție de: vârstă (cu atât mai mari cu cât copilul este mai mic), starea de sănătate a copilului şi particularităţile individuale. Rația energetică globală a copilului se diminuează odată cu vârsta (2).

Un regim hiperglucidic şi/sau hiperlipidic la sugar stimulează lipidogeneza, conducând la hipertrofia \pm hiperplazia celulelor adipoase, rezultatul final fiind apariția obezității precoce (3); un regim hipocaloric conduce la malnutriție.

„Echilibrul alimentar“ reprezintă raportul optim între principiile alimentare:

$\mathrm{P}: \mathrm{L}: \mathrm{G}=1: 2: 4$ - la nou-născut şi sugar;

$P: L: G=1: 1,2: 3,5-1$ la copilul 1-3 ani.

Asigurarea unei alimentații corespunzătoare în primii 2 ani de viață este elementul major pentru organogeneză, pentru dezvoltarea sistemului imunitar şi a sistemului nervos. Creşterea deficitară se asociază cu performanțe intelectuale şi cognitive scăzute, sistem imunitar deficitar (4).

Recomandările globale conform OMS (Organizația Mondială a Sănătății), pentru o nutriție adecvată a sugarilor şi copiilor mici, prevăd ca:

- alăptarea trebuie să înceapă cât mai devreme, în termen de o oră după naştere;

- sugarul trebuie să primească exclusiv lapte uman în primele 6 luni de viață;

- diversificarea trebuie să înceapă la 6 luni, în timp ce alăptatul se păstrează până la minimum 2 ani.

Procesul de introducere progresivă în alimentaţia sugarului după vârsta de 4-6 luni de alimente semisolide şi solide ce înlocuiesc treptat prânzurile de lapte administrate anterior este cunoscut sub denumirea de diversificare. 
Alimentaţia diversificată presupune: să se aleagă momentul potrivit; să fie corespunzătoare; să existe condiții de siguranță; să existe o tehnică de alimentaţie corespunzătoare (5).

Momentul în care se inițiază diversificarea depinde de vârsta copilului, alimentaţia anterioară şi statusul nutriţional. Au existat dispute importante în literatură referitoare la momentul optim al diversificării alimentației, fiind discutate avantajele /dezavantajele diversificării precoce (la $\sim 3$ luni) $(6,7)$.

Un studiu recent a urmărit pe parcursul mai multor ani tendințele în practicile de alimentație diversificată în rândul copiilor sub vârsta de un an, în oraşul Rio de Janeiro, Brazilia, în perioada 19982008. Concluzia a fost că, în general, tendința este de nerespectare a practicilor de diversificare (8). Ultimele recomandări ale Comitetului ESPGHAN privind momentul introducerii alimentației solide şi semisolide sunt pentru intervalul de vârstă cuprins între săptămânile 17-26 (9).

Din punct de vedere fiziologic, funcția renală şi cea digestivă se maturează după vârsta de 4 luni, astfel încât sugarul să poată tolera şi alte alimente în afară de laptele primit până la această vârstă (10).

Principiile alimentaţiei diversificate:

1. introducerea unui aliment nou se va face numai când sugarul este sănătos;

2. alegerea primului aliment de diversificare se individualizează în funcție de particularitățile de dezvoltare ale sugarului;

3. introducerea alimentului nou se va face progresiv - câte 20-30 g/zi la o masă de lapte, până la înlocuirea completă a prânzului de lapte cu noul aliment;

4. se va introduce un singur aliment nou pe săptămână - la aceeaşi masă;

5. la apariția unor tulburări digestive (vărsături şi/sau diaree) se întrerupe diversificarea şi se reia după câteva zile de la normalizarea tranzitului intestinal;

6. valoarea calorică a alimentului nou introdus (a prânzului) trebuie să fie mai mare decât a celui care este scos din alimentaţie;

7. numărul de prânzuri administrate pe zi în alimentația diversificată se va stabili în funcție de vârstă, senzația de foame-sațietate şi greutatea copilului (11).

Trebuie să reținem: cel mai bun criteriu al succesului alimentației diversificate la sugar este urmărirea curbelor de creştere şi dezvoltare.

Copilul nu va fi forțat să consume întreaga rație oferită (risc de anorexie de „opoziție“) (12). Generalizarea unui aliment care este primit cu plăcere la toate mesele perturbă echilibrul nutrițional al sugarului. Hidratarea între mese se face cu lichide neîndulcite (ceai, apă fiartă şi răcită).

La copilul alimentat diversificat trebuie să ținem cont că necesarul de lichide este acoperit de alimentele nou introduse dacă acestea sunt reprezentate de supă, legume, fructe, iaurturi. Se poate încerca administrarea după-masă sau între mese de mici cantităţi de apă, cu lingurița sau cu o căniţă adecvată vârstei. Nu se recomandă administrarea apei cu biberonul. În ultima vreme există controverse multiple în ceea ce priveşte tipul de apă administrat copiilor, fiind tot mai des promovat consumul de apă îmbuteliată (13).

La sugarul alimentat exclusiv natural şi la sugarul alimentat artificial cu formule de lapte se recomandă inițierea diversificării după vârsta de 6 luni (14). La sugarul alimentat artificial cu lapte praf convenţional/lapte de vacă se recomandă inițierea diversificării după vârsta de 4-41/2 luni (din luna a 5-a de viață) (15).

Diversificarea are o influență importantă asupra educării preferinţelor alimentare şi asupra gustului de mai târziu. Copiii au o predispoziție genetică pentru preferinţa alimentelor sărate şi dulci şi de respingere a celor acre şi amare (16).

În tabelul de mai jos (Tabelul 1) vom prezenta un model de introducere a alimentelor la sugarul alimentat natural şi la cel alimentat mixt sau artificial.

TABELUL 1. Modalități de introducere a alimentelor în funcție de vârstă (11)

\begin{tabular}{|l|l|}
\hline VÂRSTA & ALIMENTUL \\
\hline $\begin{array}{l}\text { După vârsta de 4-41⁄2 } \\
\text { luni (din luna a 5-a): }\end{array}$ & $\begin{array}{l}\text { cereale fără gluten, piure de fructe } \\
\text { supă de legume/piure de legume. }\end{array}$ \\
\hline $\begin{array}{l}\text { După vârsta de 5-6 luni } \\
\text { (din luna a 6-a): }\end{array}$ & $\begin{array}{l}\text { carne mixată de vită/pasăre } \\
\text { (20-30 g/zi), brânză calcică/brânză de } \\
\text { vacă, gălbenuş de ou. }\end{array}$ \\
\hline După vârsta de 6 luni: & cereale cu gluten. \\
\hline După vârsta de 6-7 luni: & $\begin{array}{l}\text { ficat de pasăre (alternativ cu } \\
\text { gălbenuşul de ou şi carnea albă), } \\
\text { iaurt simplu. }\end{array}$ \\
\hline După vârsta de 7-8 luni: & smântână, mămăligă. \\
\hline $\begin{array}{l}\text { După vârsta de 10 (12) } \\
\text { luni: }\end{array}$ & peşte, perişoare din carne. \\
\hline
\end{tabular}

\section{Principalele alimente folosite în diversificarea alimentației}

Cerealele se introduc în alimentaţia sugarului de la vârsta de 4-6 luni. Sunt recomandate în locul făinoaselor clasice (griş, biscuiți, făină de orez) deoarece comparativ cu acestea sunt îmbogătite cu vitamine, minerale, fibre dietetice. Cerealele se 
prepară instant, se pot combina cu piure de fructe/ brânză de vacă/iaurt la cei cu deficit ponderal şi la cei cu predispoziție de a dezvolta malnutriție (2).

În prezent există un grad de incertitudine în ceea ce priveşte când, cum şi în ce formă ar trebui introdus glutenul. De ani de zile, recomandările ESPGHAN au fost de evitare a introducerii sale sub vârsta de 4 luni, dar nu mai târziu de 7 luni, precum şi introducerea treptată, în paralel cu alăptarea. Două studii independente publicate în New England Journal of Medicine, în octombrie 2014, au ajuns la concluzia că vârsta de introducere a glutenului nu modifică riscul de a dezvolta boală celiacă şi că alăptarea la orice vârstă nu conferă protecție împotriva apariției celiachiei. În acest context, un grup de experți a considerat oportun să prezinte un document de consens cu privire la introducerea glutenului în dietă (17).

Unele firme producătoare de preparate destinate copiilor au introdus în compoziție probiotice, deoarece prin studii clinice s-a dovedit că acestea întăresc mecanismele naturale de apărare şi protejează sugarul de infecții digestive $(18,19)$.

Fructele şi legumele sunt sărace în proteine, lipide şi au un conținut variabil de glucide, dar sunt bogate în săruri minerale, calciu, fosfor, potasiu şi fier, în combinații uşor asimilabile în organism. Conţinutul de celuloză poate fi iritant pentru mucoasa digestivă a sugarului, de aceea se dă la început sub formă de sucuri, apoi sub formă de piureuri/supă/compot. Se recomandă precauții pentru cele cu potențial alergizant (zmeură/căpşuni/fragi/ kiwi), acestea nefiind indicate sub vârsta de 1 an.

Vitaminele sunt factori de nutriţie şi sunt cofactori esențiali într-o varietate de căi metabolice, necesarul variind cu vârsta şi/sau cu existența unor boli. Majoritatea vitaminelor nu pot fi sintetizate de către organism, de aceea asigurarea unui regim alimentar echilibrat îi va oferi copilului necesarul de vitamine. Există două excepții: vitamina D în primii ani de viață şi vitamina $K(20)$.

În stabilirea unei diete zilnice trebuie ținut cont şi de faptul că mineralele nu se regenerează în organismul uman, de aceea trebuie obținute din dietă (13).

Dietele vegetariană, lacto-vegetariană şi rawvegană, la sugarii şi copiii mici nu sunt recomandate, deoarece nu asigură necesarul de proteine - aminoacizi esențiali şi fier, indispensabile pentru o dezvoltare optimă a unui organism cu nevoi speciale de creştere şi dezvoltare. Este imperios necesar ca dieta copilului să conțină un minimum de $500 \mathrm{ml}$ de lapte uman sau formulă de lapte şi/sau produse lactate (16).
Carnea se administrează după vârsta de 5-6 luni, 20-30 g/zi, amestecată în supă/piure de legume. Se recomandă carnea de pasăre/curcan/vită fiartă şi mixată. Carnea tocată se administrează sub formă de perişoare după vârsta de 10-12 luni. S-a observat că un aport scăzut de alimente care conțin proteine de înaltă valoare biologică conduce la dezechilibre nutriționale (21).

O altă sursă de proteine şi fier o reprezintă gălbenuşul de ou, care se va administra după vârsta de 5-6 luni, de 2-3 ori/săptămână, cu supă sau piure de legume; albuşul de ou se va introduce după vârsta de 1 an, fiind puternic alergizant. Ficatul de pasăre/vită fiert şi mixat se administrează după vârsta de 6-7 luni, în cantitate de 20-30 g/zi, în supă/piure de legume, în zilele în care sugarul nu primeşte gălbenuş sau carne. Peştele alb, fiert, se recomandă în alimentația sugarului după vârsta de 10-12 luni, deoarece are potențial alergizant.

Lactatele vor fi oferite sub formă de brânză slabă de vaci sau iaurt. Este contraindicată folosirea excesivă a iaurtului cu fructe din comerț, deoarece acesta conține mult zahăr adăugat şi favorizează apariția obezității şi dezvoltarea preferinței pentru gustul dulce. Iaurtul se recomandă după vârsta de 6-7 luni în combinație cu cereale sau piure de fructe. Brânza de vaci se utilizează în alimentația diversificată după vârsta de 5-6 luni şi în regimurile hiperproteice recomandate sugarilor cu distrofie. Brânza telemea de vacă (desărată) se administrează de la vârsta de 8-9 luni, în amestec cu mămăligă/ paste făinoase (budinci), iar brânzeturile fermentate după vârsta de 1 an.

Uleiul de porumb/măsline/floarea soarelui/soia/ susan bogat în acizi graşi nesaturați se adaugă în piureul de legume după vârsta de 5-6 luni (1 linguriță/zi) cu scopul de a creşte valoarea calorică a prânzului. Untul bogat în acizi graşi saturaţi şi colesterol predispune la ateromatoză (primele modificări la nivel vascular apar în perioada copilăriei), de aceea nu se recomandă folosirea sa în exces.

Biscuiții se pot administra după 6 luni, sfărâmați, în asociere cu piureul de fructe. Pâinea albă se introduce după vârsta de 8 luni dacă masticaţia o permite. Pastele făinoase (fidea) se utilizează începând cu vârsta de 8 luni, fierte în supă.

Mierea de albine se va introduce în alimentație după vârsta de 1 an, din cauza riscului de infecție cu Clostridium botulinum (22), sau mai devreme dacă produsul folosit este tratat termic şi sub presiune crescută pentru inactivarea sporilor şi, de asemenea, din cauza potențialului alergizant pe care îl are.

Preparatele industriale sunt $\mathrm{o}$ alternativă foarte bună pentru mesele de legume sau fructe. Controlul 
temperaturii şi al duratei proceselor de preparare, pasteurizarea şi sterilizarea elimină microorganismele patogene care ar putea contamina mâncarea şi le păstrează valoarea nutritivă (23).

Practic, un sugar diversificat poate să primească 5 prânzuri (p) x $200 \mathrm{ml}$ sau 6 p x 160 (170) ml. Acestea vor fi distribuite astfel:

- 1 p x 200-250 ml lapte uman/formulă de lapte \pm cereale

- 1p x piure de fructe (măr/piersică/caisă) cu brânză/cereale

- 1 x x piure de legume cu carne mixată/gălbenuş de ou/ficat

- $1 \mathrm{p} x$ iaurt/brânză cu cereale

- 1p x 200-250 ml lapte uman/formulă de lapte \pm cereale.

Trecerea de la alimentația bazată exclusiv pe lapte la cea diversificată, administrată cu linguriţa presupune noi situații comportamentale, la care trebuie să se adapteze atât mama, cât şi copilul. Un aspect important îl constituie şi dezvoltarea neuromotorie; totodată, apar şi mişcările coordonate de apucare cu ajutorul buzelor şi a limbii a alimentului oferit. Alimentele noi vor fi pasate până la apariția primilor dinți, apoi zdrobite. După vârsta de 9 luni poate apuca alimentele direct cu mâna sau cu lingurița pe care o va manevra cu ambele mâini. Pentru alimentele lichide sau semisolide este bine să folosim cana pentru administrare. După vârsta de 6-9 luni, sugarul poate şi este recomandat să ia masa o dată pe zi cu familia.

Situații particulare importante sunt în cazul diversificării prematurilor, la care trebuie ținut cont de vârsta corectată şi în cazul sugarilor cu istoric de atopie familială. Diversificarea la copilul cu atopie familială este un subiect intens studiat în prezent, patologia de tip alergic fiind într-o continuă dinamică, având în vedere utilizarea pe scară largă a preparatelor alimentare intens prelucrate industrial, în defavoarea celor ecologice (24-26).

\section{CONCLUZII}

Alimentația diversificată reprezintă o etapă importantă în viața sugarului şi a familiei, cu impact pe termen lung asupra creşterii şi dezvoltării armonioase. Familia trebuie conştientizată de importanța cooperării şi respectării recomandărilor medicului de familie/specialist pediatru, în vederea trecerii fără incidente negative la o alimentație completă, echilibrată, asemănătoare alimentației adultului.

La sugarul alimentat exclusiv natural şi la sugarul alimentat artificial cu formule de lapte se recomandă inițierea diversificării după vârsta de 6 luni. La sugarul alimentat artificial cu lapte praf convențional sau cu lapte de vacă se recomandă iniţierea diversificării după vârsta de 4-41/2 luni (din luna a 5-a de viață).

Diversificarea are o influență importantă asupra educării preferinţelor alimentare şi asupra gustului de mai târziu. Greşelile alimentare din primul an de viață au repercursiuni asupra morbidității, atât în copilărie, cât şi la vârsta de adult.

Situaţii particulare importante sunt în cazul diversificării prematurilor, la care trebuie ținut cont de vârsta corectată şi în cazul sugarilor cu istoric de atopie familială. Având în vedere tendințele actuale din alimentația adultului, regim vegetarian, lactovegetarian şi raw-vegan, trebuie precizat că la sugarii şi copiii mici acestea nu sunt recomandate, deoarece nu asigură necesarul de proteine - aminoacizi estențiali şi fier. 